\title{
Pelatihan Pengelolaan Kelas Bagi Guru Sekolah untuk Mencapai Tujuan Pembelajaran
}

\author{
Juniriang Zendrato \\ Universitas Pelita Harapan \\ juniriang.zendrato@uph.edu
}

\begin{abstract}
Abstrak
Keterampilan para guru di dalam mengelola afeksi saat berhadapan dengan para murid, rekan guru lainnya, pimpinan, dan orang tua menentukan pencapaian tujuan pembelajaran di dalam kelas. Para guru di Sekolah Mardi Yuana Cilegon membutuhkan waktu dan kesempatan untuk mengevaluasi dan merefleksikan pengalaman mengajar mereka selama ini di dalam kesempatan formal sekolah. Oleh karena itu, tujuan dari pelatihan ini adalah untuk memperkenalkan dan melatihkan praktik-praktik pengelolaan kelas yang efektif kepada guru. Pelatihan ini diberikan selama enam kali pertemuan. Metode pelaksanaan adalah dengan menggunakan siklus pelatihan tradisional yang meliputi empat bagian yaitu penilaian, perencanaan, penyampaian, dan evaluasi dengan LEARN sebagai pusatnya. Hasil kegiatan menunjukkan ada dua faktor yang menjadi evaluasi para peserta pelatihan: internal dan eksternal. Untuk faktor internal yang menyangkut diri peserta, 78\% peserta pelatihan menyatakan bahwa motivasi mereka sebagai guru untuk bersedia menjadi lebih peka terhadap wawasan dan ilmu yang telah mereka peroleh dan memberikan ruang untuk evaluasi serta refleksi terhadap pengalaman mereka mengajar selama ini meningkat. Untuk faktor eksternal yang di luar diri peserta, $82 \%$ peserta pelatihan menyatakan bahwa fasilitas yang dipakai untuk pelatihan cukup memadai, materi pelatihan sesuai dengan kebutuhan, dan para pelatih dapat menyampaikan konsep dengan metode yang tepat serta waktu pelaksanaan yang dipilih cukup efektif.
\end{abstract}

Kata kunci: pengelolaan kelas, kompetensi guru, tujuan pembelajaran

\section{PENDAHULUAN}

Sekolah Mardi Yuana yang berlokasi di Cilegon merupakan kampus terpadu yang terdiri dari tiga departemen yaitu TK, SD, dan SMP. Tantangan utama yang selama ini menjadi fokus perhatian dari para pimpinan sekolah adalah afeksi para guru terhadap murid yang berdampak pada komunikasi guru kepada seluruh komunitas sekolah dan ketercapaian tujuan pembelajaran. Masalah afeksi ini sudah ditindaklanjuti dengan melakukan pelatihan guru di semester sebelumnya yang berfokus pada peningkatan afeksi melalui pelatihan positive expectation yang didasarkan pada perspektif Alkitabiah.
Berdasarkan Peraturan Menteri Pendidikan Nasional Republik Indonesia No. 16 Tahun 2007, ada empat kompetensi yang harus dimiliki dan dikuasai guru untuk mengajar murid yaitu kompetensi pedagogi, kompetensi sosial, kompetensi profesional, dan kompetensi kepribadian ("Standar Pendidik Dan Tenaga Kependidikan," n.d.). Empat kompetensi itu berasal dari tiga ranah dalam diri guru yaitu afektif, keterampilan, dan kognitif. Hal ini yang oleh Miller and Night disebut pendidikan yang holistis yaitu integrasi antara tubuh, pikiran, dan spiritualitas di dalam proses belajar mengajar (Miller \& Nigh, 2017, h. xii). Tubuh berhubungan dengan keterampilan atau psikomotorik, pikiran 
berhubungan dengan kognitif, dan spiritualitas berhubungan dengan afektif.

Ranah keterampilan guru salah satunya dapat terlihat dari keterampilan mengelola kelas. Keterampilan ini membantu guru untuk menciptakan suasana belajar mengajar yang kondusif. Suasana kelas yang kondusif akan meningkatkan motivasi murid untuk mengikuti pembelajaran dengan baik (Librianty, 2020, h.141-142).

Ranah kognitif berhubungan dengan kemampuan guru menentukan tujuan pembelajaran. Guru yang menyusun kegiatan belajarnya berdasarkan tujuan yang akan dicapai akan selalu memastikan bahwa setiap kegiatan yang dilakukan murid memang mengarah kepada tujuan yang sudah ditetapkan. Oleh karena itu, guru perlu untuk menguasai konsep yang akan disampaikan kepada murid (Johnson dkk., 2014).

Ranah afektif guru juga memegang peranan yang sangat penting dalam proses belajar mengajar. Afektif bukan hal yang bertentangan dengan kognitif. Justru pada saat afektif dan kognitif dipakai secara bersamaan, fondasi pembelajaran yang dibangun akan lebih kuat (Zumaeta Arista dkk, 2018, h. 453).

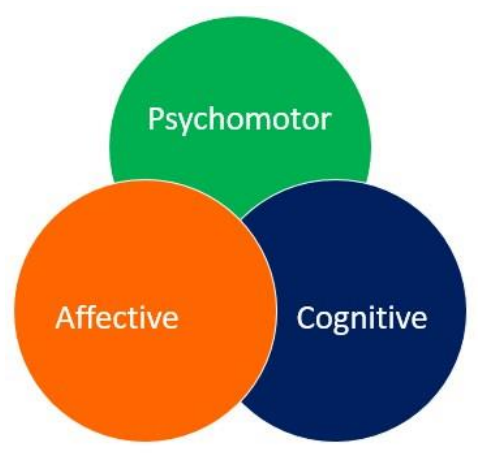

Gambar 1. Ranah Pembelajaran

Ketiga ranah pembelajaran tersebut saling berkaitan erat dan tidak terpisah. Itulah yang disebut dengan pendidikan yang utuh atau holistis yang dijelaskan melalui Gambar 1. Pendidikan holistis inilah yang menjadi tujuan dari pendidikan di Sekolah Mardi Yuana Cilegon.
Berdasarkan analisis situasi, guru-guru di Sekolah Mardi Yuana Cilegon memiliki masalah 1) dengan para murid, sesama guru, orang tua, dan pimpinan, karena mereka merasa dominan di dalam mengajar dan berelasi; 2) dalam pengelolaan kelas karena mereka mengatur kelas sesuai dengan keinginannya sendiri tanpa memikirkan tujuan pembelajaran yang sudah ditetapkan sekolah dan kondisi para siswa; 3) dalam menyusun rencana pembelajaran, karena mereka merasa sudah menguasai materi pelajaran dan tidak perlu belajar lagi.

Seluruh permasalahan di atas perlu ditangani dengan segera oleh pimpinan sekolah, karena guru sebagai kurikulum yang hidup memegang peran utama dan penting di dalam mencapai kesuksesan kegiatan belajar mengajar di kelas. Seperti yang dinyatakan oleh Anditya bahwa tanggung jawab guru Kristen tidak hanya berhenti dalam menunjukkan profesionalitas untuk memenuhi ekspektasi murid, tapi juga membawa mereka ke jalan yang benar dan berkenan bagi Tuhan dalam belajar yaitu dengan tidak menjadi berpusat hanya kepada diri sendiri dalam mencapai tujuan mereka (Anditya dkk., 2017, h. 19). Oleh karena itu, permasalahan guru di kelas bila tidak segera ditangani dapat berdampak pada ketidaktercapaian tujuan pembelajaran, penurunan tingkat kepercayaan orang tua terhadap guru dan sekolah, penurunan tingkat kepercayaan para pimpinan sekolah kepada guru, dan memburuknya relasi guru dengan rekan sekerja. Mengingat dampak pengajaran guru ada pada beberapa area yang esensial, para pimpinan sekolah harus segera bertindak untuk menangani hal ini.

Permasalahan yang menyangkut relasi guru dengan sesama anggota komunitas sekolah telah ditindaklanjuti melalui pelatihan guru pada semester sebelumnya dengan tema positive expectation. Identifikasi yang dilakukan oleh para pimpinan sekolah terhadap masalah pengelolaan kelas juga terlihat dari frekuensi para guru yang mengungkapkan keluhan tentang permasalahan di kelas yang disampaikan melalui forum tanya jawab dan diskusi selama pelatihan positive expectation berlangsung dan dari jurnal refleksi selama pelatihan. 


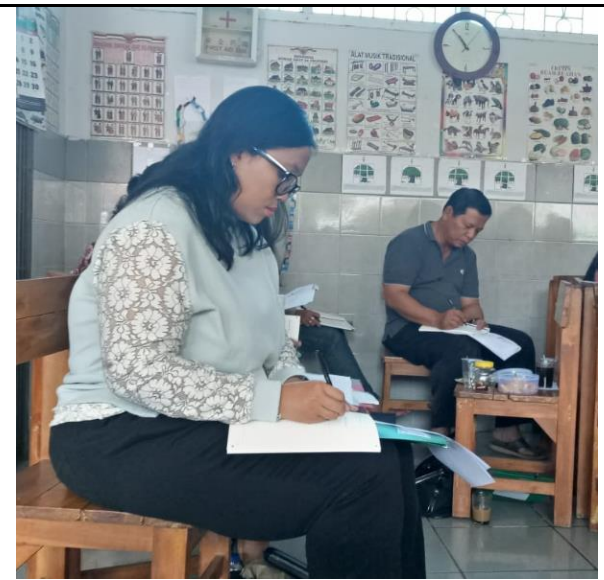

Gambar 2. Kegiatan Menulis Jurnal Refleksi

Oleh sebab itu, pada semester ini, solusi yang ditawarkan pada pimpinan sekolah adalah pemberian latihan untuk bidang keterampilan pengelolaan kelas sebagai lanjutan dari pelatihan positive expectation yang telah dilaksanakan sebelumnya. Tujuan dari pelatihan ini adalah untuk memperkenalkan dan melatihkan praktik-praktik pengelolaan kelas yang efektif kepada guru. Riset menunjukkan bahwa kelas yang dikelola dengan baik dan menarik mendorong ketercapaian tujuan pembelajaran dan merangsang perilaku positif murid (Brummelen, 2009, h. 83). Sedangkan menurut Wong \& Wong (2009, h. 106) pengelolaan kelas mengacu pada semua hal yang dilakukan guru untuk mengatur dan menata semua yang terlibat dalam proses pembelajaran, baik itu murid, waktu, ruang, dan bahan pembelajaran. Dengan kata lain, pengelolaan kelas berhubungan dengan tujuan pembelajaran, perilaku murid, proses pembelajaran, dan bahan ajar. Pengelolaan kelas selalu membutuhkan perencanaan yang matang, pelaksanaan yang teliti, dan evaluasi untuk perbaikan di pertemuan berikutnya.

Untuk memiliki keterampilan pengelolaan kelas yang efektif, guru perlu dilatih. Oleh karena itu, program pelatihan ini dirancang dengan cakupan konsep sebagai berikut 1) kelas yang dikelola dengan penuh perencanaan; 2) arti kelas yang siap; 3) pemberian tugas kepada murid; 4) pengaturan tempat duduk di kelas; dan 5) perkenalan diri guru di kelas (Wong \& Wong, 2009, h. 100). Konsep ini tidak hanya menyangkut peningkatan kognitif, tetapi juga keterampilan dan afektif guru sebagai peserta pelatihan.

Hasil dari pelatihan ini diharapkan guru memiliki kondisi kelas yang semakin membaik, karena guru memiliki motivasi internal untuk mempersiapkan kegiatan belajar dan mengajar. Selain itu, murid juga tertarik dan mau terlibat di dalam semua kegiatan kelas. Harapannya, bila kondisi ideal ini terwujud, tujuan pembelajaran akan tercapai.

\section{METODE}

Pelatihan ini menggunakan siklus pelatihan tradisional yang meliputi empat bagian yaitu penilaian, perencanaan, penyampaian, dan evaluasi dengan LEARN sebagai pusatnya. Konsep LEARN dikembangkan oleh Furjanic and Trotman (2000, h. 2). LEARN merupakan proses alami yang dilalui oleh pembelajar sebelum mereka merasa memiliki dan menggunakan konsep yang diterima dari pelatihan. LEARN merupakan akronim yang menggambarkan lima langkah yang harus diikuti saat peserta pelatihan mulai masuk, mempraktikkan, mengaplikasikan, dan menginternalisasi keterampilan dan konsep yang disampaikan. L adalah Listen and Understand (Mendengarkan dan Memahami), E adalah Evaluate and Decide (Mengevaluasi dan Memutuskan), A adalah Attempt and Build (Berusaha dan Membangun), $\mathrm{R}$ adalah Return and Apply (Kembali dan Mengaplikasikan), dan $\mathrm{N}$ adalah Natural Transition (Transisi Alami). Proses pelatihan dilukiskan dalam Gambar 3 di bawah ini.

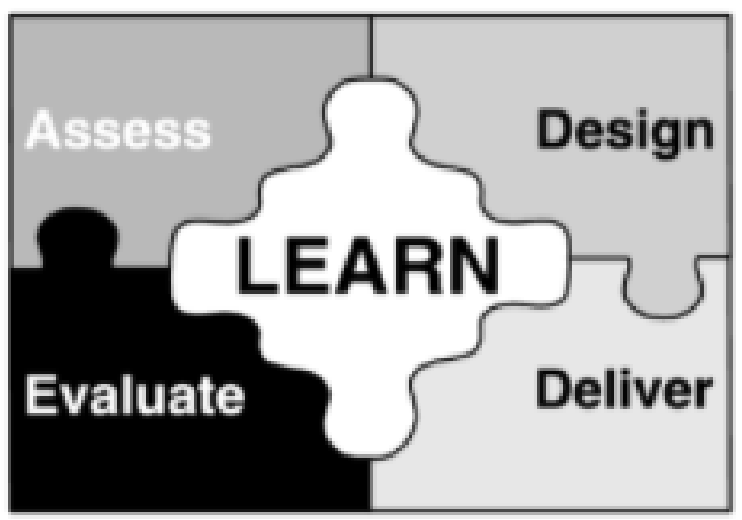

Gambar 3. Proses Pelatihan 
Yang pertama tim PkM melakukan bagian pertama yaitu tahap penilaian. Menurut Furjanic and Trotman (2000, h. 7), tahap penilaian adalah tahap mengklarifikasi permohonan $\mathrm{PkM}$, mempelajari alasan permohonan, dan menentukan apakah pelaksanaan pelatihan merupakan merupakan jawaban yang tepat.

Setelah tim PkM memutuskan pelatihan sebagai pemecahan masalah, tahap kedua perencanaan dilakukan. Tim PkM mengumpulkan informasi, mengidentifikasi keterampilan yang sudah dimiliki oleh para guru dan kesenjangannya, mengembangkan tujuan pelatihan, merekrut mahasiswa tutor, mengembangkan topik pelatihan dan materi serta aktivitas pelatihan, dan menentukan jadwal serta bahan-bahan pelatihan yang dibutuhkan (Furjanic \& Trotman, h. 23).

Tahap ketiga adalah tahap penyampaian konsep. Para pelatih harus memahami andragogi peserta yang memiliki kebutuhan belajar yang berhubungan hidup, pekerjaan, dan penyelesaian masalah. Para pelatih juga mempertimbangkan gaya belajar para peserta. Oleh karena itu, kegiatan pelatihan bervariasi di tiap pertemuannya, sehingga pelatihan ini dapat mengakomodasi berbagai kebutuhan tersebut (Furjanic \& Trotman, h. 62).

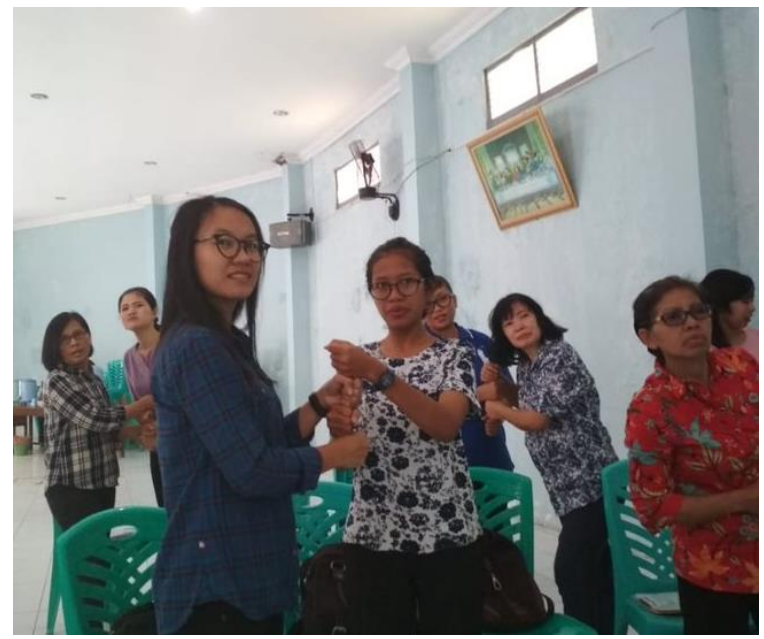

Gambar 4. Kegiatan Kelas Berpasangan
Tahap keempat berbicara tentang evaluasi pelatihan. Evaluasi program ini membantu para pimpinan sekolah dan pelatih pengajar untuk menilai keefektifan program pelatihan yang diselenggarakan selama pelaksanaan pelatihan (Furjanic \& Trotman, h. 82). Tiap akhir pelatihan, para peserta diminta mengevaluasi materi pelatihan, pelatih, alat dan media belajar, dan motivasi peserta. Selain itu, para peserta diberi waktu 10 menit terakhir di tiap pertemuan untuk menuliskan refleksi pelatihan mereka yang berisi ide-ide baru yang didapat dan dapat membantu mereka mengajar di kelas dengan lebih baik. Selain itu, juga refleksi tentang hal-hal menarik yang ditemukan, yang belum dipahami, dan yang ingin diketahui lebih lanjut. Menurut Zendrato, refleksi diri penting untuk dilakukan guru, refleksi ini merupakan proses koreksi diri sendiri yang dilakukan dengan jujur dan terbuka. Guru bukan hanya mau mengakui kelemahan diri, tetapi juga harus bersedia melakukan perubahan atau perbaikan. (Zendrato dkk., 2019, h. 130). Jurnal refleksi peserta ini selalu dibaca para pelatih dan diberi umpan balik secara bergantian, sehingga setiap pertanyaan atau permasalahan yang ditemukan selama pelatihan segera terbahas dan tertangani. Gambar 5 adalah template jurnal refleksi yang diisi oleh peserta di akhir tiap sesi pertemuan.

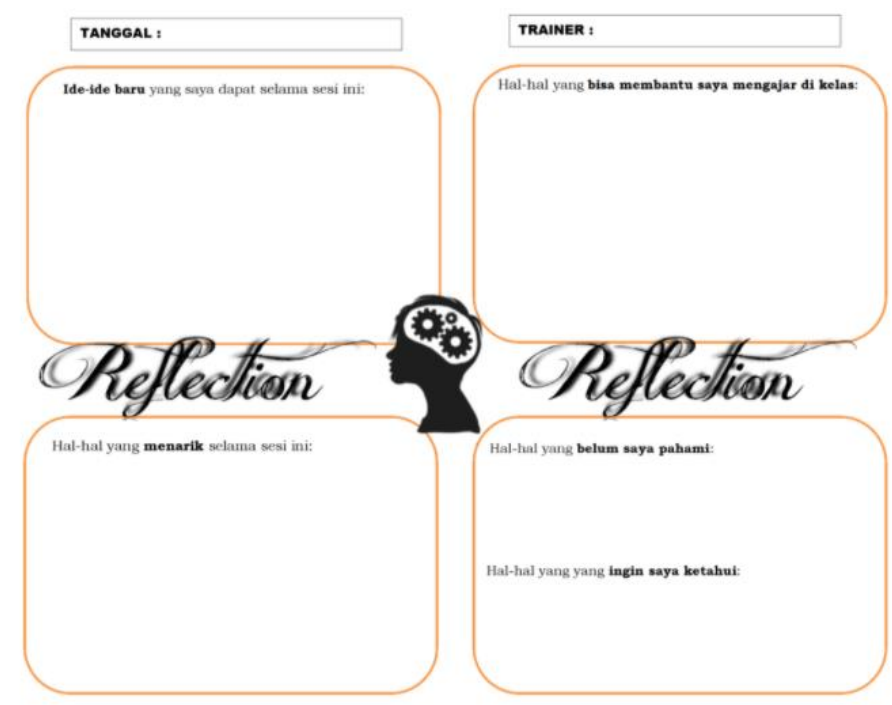

Gambar 5. Lembar Refleksi 
Konsep LEARN diaplikasikan di sepanjang kegiatan pelatihan. Yang pertama adalah mendengarkan dan memahami. Para pelatih perlu membangun lingkungan yang aman dengan berusaha mengenali para peserta, memberikan rules dan procedures yang jelas selama pelatihan, dan menciptakan suasana yang kondusif untuk belajar, dan menyampaikan tujuan pelatihan ini (Furjanic \& Trotman, h. 101).

Yang kedua adalah mengevaluasi dan memutuskan. Pada tahap ini, pelatih harus mampu menciptakan situasi belajar yang dapat melibatkan peserta dalam proses belajar dan meyakinkan mereka bahwa mereka harus secara aktif berpartisipasi dalam proses belajar (Furjanic \& Trotman, h. 117).

Yang ketiga adalah berusaha dan membangun. Pada tahap ini, pelatih berusaha untuk memilih aktivitas yang akan membantu peserta mengingat konsep yang telah dipelajari, menginternalisasi nilai-nilai secara pribadi, dan membangun keterampilan yang mereka butuhkan untuk mengelola kelas (Furjanic \& Trotman, h. 135).

Yang keempat adalah kembali dan mengaplikasikan. Pada tahap ini, pelatih menyiapkan aktivitas tindak lanjut dan alat yang akan membantu peserta di dalam menerapkan hasil pelatihan untuk mengelola kelas (Furjanic \& Trotman, h. 167).

Yang kelima adalah transisi alami. Hasil pelatihan yang berhasil melebihi aplikasi pekerjaan biasanya membuat perbedaan dalam bekerja. Namun transisi tidak secara langsung dapat terlihat karena berhubungan dengan perubahan perilaku yaitu proses pengelolaan kelas (Furjanic \& Trotman, h. 191).

\section{HASIL DAN PEMBAHASAN}

\section{Pelaksanaan}

Pelaksanaan PkM ini dimulai dengan tahap identifikasi masalah dan analisis kebutuhan yang dilakukan dengan beberapa kali pertemuan beberapa dengan pimpinan sekolah membahas hasil evaluasi dan tindak lanjut dari pelatihan guru dengan tema positive expectation yang diselenggarakan pada semester sebelumnya.

Setelah tercapai para pimpinan sekolah memutuskan untuk meneruskan program pelatihan, Tim PkM yang terdiri dari 4 dosen pelatih mulai mengembangkan tujuan pelatihan, merekrut 5 mahasiswa tutor, mengembangkan topik pelatihan dan materi serta aktivitas pelatihan. Tabel 1 adalah jadwal pelatihan yang terdiri dari tanggal pelaksanaan, topik per pertemuan, pelatih yang bertugas, dan alokasi waktu.

Tabel 1. Jadwal Pelatihan

\begin{tabular}{|c|c|c|c|}
\hline Tanggal & Materi & Pemateri & Waktu \\
\hline 9/14/2019 & Kelas dengan Manajemen yang Baik & $\begin{array}{l}\text { Asih Enggar Susanti, M.Pd. } \\
\text { Juniriang Zendrato, M.Pd., M.Ed. }\end{array}$ & 120 menit \\
\hline \multirow{2}{*}{$10 / 12 / 2019$} & Kelas yang Siap & Bertha Natalina Silitonga, S.T.P., M.Sc. & $90^{\prime}$ \\
\hline & Pemberian Tugas pada Siswa & Asih Enggar Susanti, M.Pd. & $90^{\prime}$ \\
\hline $11 / 16 / 2019$ & Pengaturan Tempat Duduk & $\begin{array}{l}\text { Juniriang Zendrato, M.Pd., M.Ed. } \\
\text { Dra.Christina Purwanti, M.Pd. }\end{array}$ & $120^{\prime}$ \\
\hline \multirow{2}{*}{$11 / 23 / 2019$} & Perkenalan Diri di Kelas & Dra.Christina Purwanti, M.Pd. & $90^{\prime}$ \\
\hline & Wrap-Up Session & Bertha Natalina Silitonga, S.T.P., M.Sc. & $90^{\prime}$ \\
\hline \multicolumn{3}{|c|}{ TOTAL } & 600 menit \\
\hline
\end{tabular}

Di tiap pertemuannya, Tim PkM juga merancang aktivitas pelatihan yang bervariasi supaya dapat mengakomodasi berbagai gaya belajar peserta. Hal ini juga dapat meningkatkan motivasi belajar peserta pelatihan. Pendapat ini didukung oleh Antelm yang mengatakan bahwa penentuan aktivitas yang berhubungan dengan gaya belajar akan membantu peserta pelatihan untuk lebih fleksibel dan dapat menentukan cara belajar mereka sendiri (Antelm-Lanzat dkk., 2020, h. 1).

Tim PkM juga merancang komponen yang akan dituliskan pada template jurnal refleksi dan poin-poin yang akan dievaluasi di setiap akhir pertemuan. Tabel 2 merupakan lembar evaluasi yang diisi oleh para peserta di setiap pertemuan. 
Tabel 2. Lembar Evaluasi

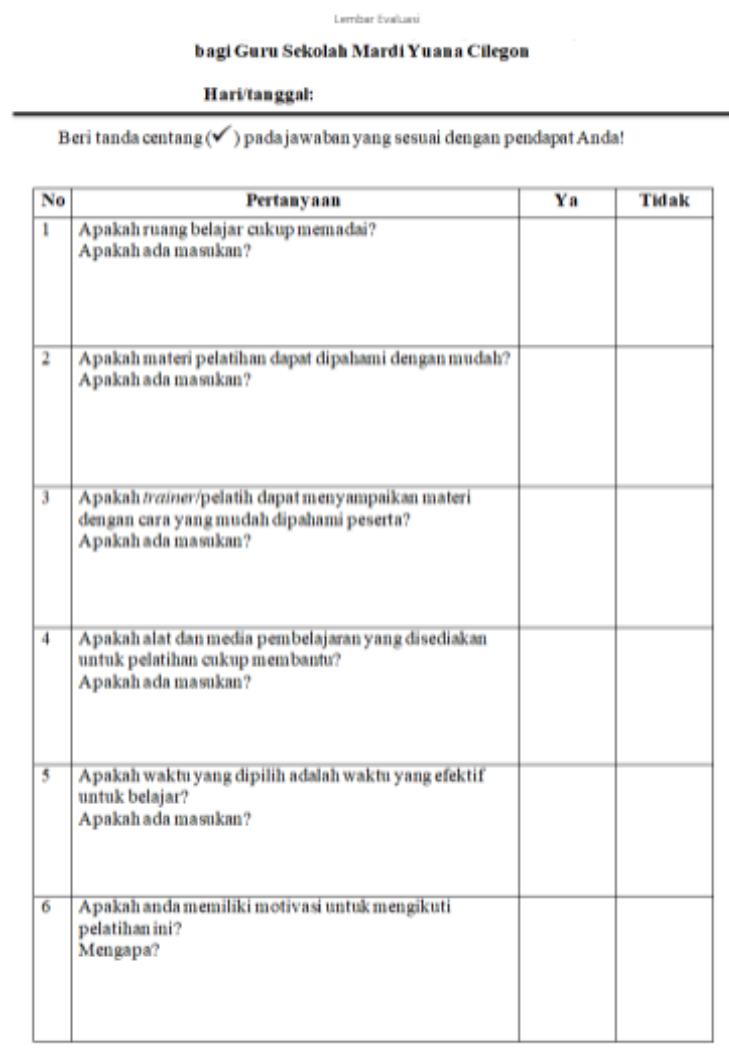

Secara detail, konsep LEARN dapat terlihat dari beberapa akitivitas pelatihan. Konsep mendengarkan dan memahami, salah satunya terlihat dari penyampaian tujuan pelatihan ini di pertemuan pertama. Gambar 6 merupakan salah satu slide yang disampaikan di pertemuan pertama yang berisi penyampaian tujuan pelatihan.

\section{Tujuan Pelatihan}

Meningkatkan keterampilan mengelola kelas dengan pembahasan topik-topik sebagai berikut:

1. Kelas dengan manajemen yang baik

2. Kelas yang siap

3. Perkenalan di kelas

4. Pemberian tugas pada siswa

5. Pengaturan tempat duduk

\section{QUPH}

Gambar 6. Slide Tujuan Pelatihan
Peserta akan belajar dengan efisien ketika mereka mengetahui tujuan atau aktivitas pembelajaran. Hal ini membuat para peserta pelatihan menjadi fokus. Kondisi pembelajaran semacam ini akan mengurangi kecemasan peserta di dalam mencapai kesuksesan sekaligus membangun motivasi intrinsik peserta (Pitler \& Stone, 2012).

Konsep mengevaluasi dan memutuskan terlihat salah satunya dari usaha menciptakan situasi belajar yang melibatkan peserta dalam proses belajar dan meyakinkan mereka bahwa mereka harus secara aktif berpartisipasi dalam proses belajar. Gambar 7 melukiskan kegiatan diskusi kelompok yang memberikan kesempatan kepada setiap peserta untuk mengekspresikan pendapat mereka dalam ruang lingkup yang lebih kecil.

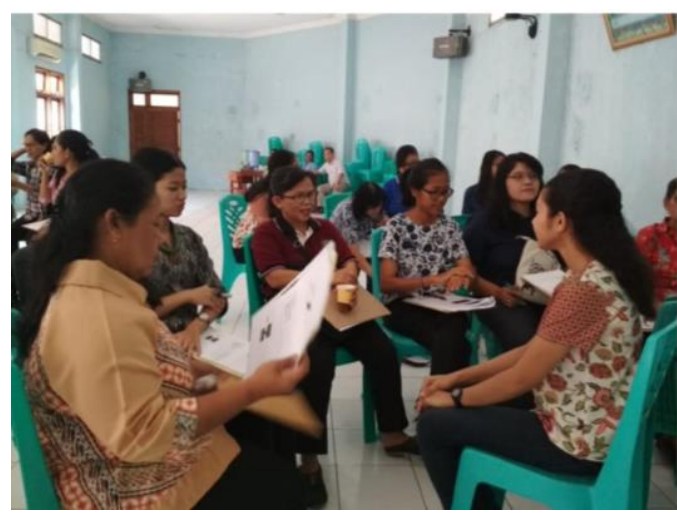

Gambar 7. Diskusi Kelompok

Konsep berusaha dan membangun terlihat dari usaha para pelatih untuk memilih aktivitas yang akan membantu peserta mengingat konsep yang telah dipelajari, menginternalisasi nilai-nilai secara pribadi, dan membangun keterampilan yang mereka butuhkan untuk mengelola kelas. Salah satu contohnya dideskripsikan pada Gambar 8 yaitu aktivitas individu dimana tiap peserta diminta untuk merancang satu tugas sederhana yang dapat dikerjakan oleh para murid pada hari pertama sekolah. 


\section{Pikirkan Mapel Bapak Ibu, Lalu buatlah 1 tugas sederhana yang dapat dikerjakan siswa pada saat kelas dimulai}

jurnal refleksi guru juga dikumpulkan oleh pelatih pelatih untuk diberi umpan balik.

Pertemuan keempat dilaksanakan pada Sabtu (16 November 2019), pkl. 09.00-11.00 di Aula Sekolah Mardi Yuana Cilegon. Pelatihan ini dihadiri oleh 2 dosen pelatih, 5 mahasiswa tutor, dan 46 guru. Materi pelatihan adalah bagaimana pengaturan tempat duduk di kelas. Di dalam sesi ini juga dibagikan angket evaluasi pelatihan di akhir sesi pertemuan. 5 jurnal refleksi guru juga dikumpulkan oleh pelatih untuk diberi umpan balik.

Pertemuan kelima dan keenam dilaksanakan

Konsep kembali dan mengaplikasikan terlihat dari aktivitas pelatih yang menyiapkan aktivitas tindak lanjut yang akan membantu peserta di dalam menerapkan hasil pelatihan untuk mengelola kelas (Furjanic \& Trotman, h. 167). Salah satunya dengan pemberian umpan balik refleksi tiap peserta.

Yang terakhir adalah konsep transisi alami. Biasanya masa transisi membutuhkan waktu yang lama dan tidak secara langsung dapat terlihat karena berhubungan dengan perubahan perilaku yaitu proses pengelolaan kelas. Oleh karena itu, para pimpinan sekolah yang akan terus memantau perkembangan tiap peserta pelatihan di dalam keseharian tugas mengajar mereka di kelas.

Secara keseluruhan pelatihan dilaksanakan selama enam pertemuan. Pertemuan pertama dilaksanakan pada Sabtu (14 September 2019), pkl. 09.00-11.00 di Aula Sekolah Mardi Yuana Cilegon. Pelatihan ini dihadiri oleh 2 dosen pelatih, 5 mahasiswa tutor, dan 51 guru. Materi pelatihan adalah perkenalan, pendahuluan, dan penjelasan tujuan pelatihan. Di dalam sesi ini dibagikan angket evaluasi pelatihan di akhir sesi pertemuan. 5 jurnal refleksi guru dikumpulkan oleh pelatih untuk diberi umpan balik.

Pertemuan kedua dan ketiga dilaksanakan pada Sabtu (12 Oktober 2019), pkl. 08.00-12.00 di Aula Sekolah Mardi Yuana Cilegon. Pelatihan ini dihadiri oleh 2 dosen pelatih, 5 mahasiswa tutor, dan 49 guru. Materi pelatihan adalah bagaimana memiliki kelas yang siap dan pemberian tugas kepada murid. Di dalam sesi ini juga dibagikan angket evaluasi pelatihan di akhir sesi pertemuan. 5

\section{Hasil Kegiatan}

Secara keseluruhan, evaluasi dari peserta pelatihan yang diberikan di tiap akhir sesi pertemuan adalah sebagai berikut sebagaimana digambarkan pada Gambar 9. Secara rata-rata sebanyak $81 \%$ peserta menyatakan bahwa ruang yang dipakai untuk pelatihan cukup memadai. Ada $19 \%$ peserta yang lebih memilih ruang terbuka untuk acara pelatihan.

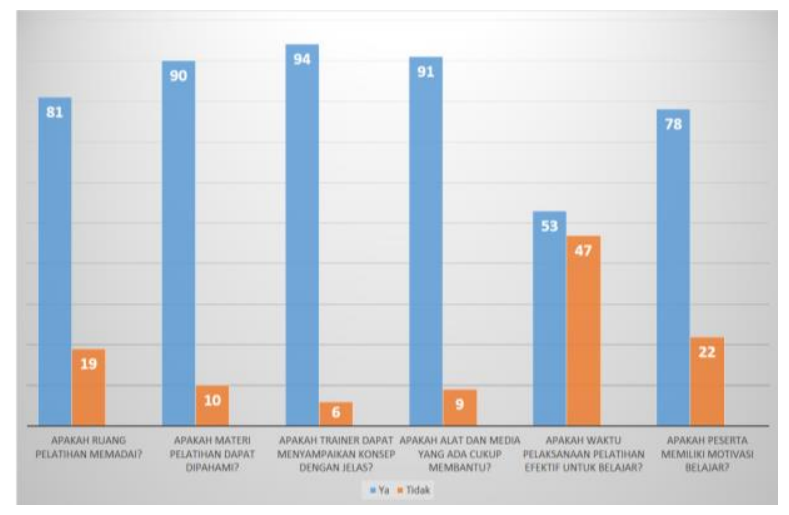

Gambar 9. Rekapitulasi Angket Evaluasi Pelatihan

90\% peserta pelatihan dapat memahami materi pelatihan. Namun ada $10 \%$ peserta yang tidak mendapatkan hardcopy materi secara lengkap sesuai

$$
\text { Pendidikan }
$$

803 
dengan tampilan powerpoint pelatih, sehingga hal ini menjadi kendala bagi mereka untuk memahami konsep yang diberikan secara utuh. 90\% peserta pelatihan dapat memahami konsep yang disampaikan oleh pelatih. Namun ada $6 \%$ peserta yang berpendapat bahwa konsep yang disampaikan pelatih bersifat teoritis dan idealis, kurang sesuai dengan realita sekolah. $91 \%$ peserta pelatihan berpendapat bahwa alat dan media yang disediakan untuk pelatihan sudah mencukupi. Namun ada $9 \%$ peserta menginginkan adanya meja untuk menulis, tidak hanya kursi dan writing pad saja. 53\% peserta menyatakan bahwa waktu pelaksanaan pelatihan yang dipilih cukup efektif untuk belajar. Namun ada 47\% peserta yang menyatakan bahwa waktu pelatihan yang dilaksanakan di tiap Sabtu tidak efektif, karena mengambil waktu keluarga. 78\% peserta menyatakan mereka memiliki motivasi belajar selama pelatihan ini. Namun ada $22 \%$ peserta menyatakan bahwa mereka tidak memiliki motivasi karena pelatihan ini dirasa terlalu kaku dan

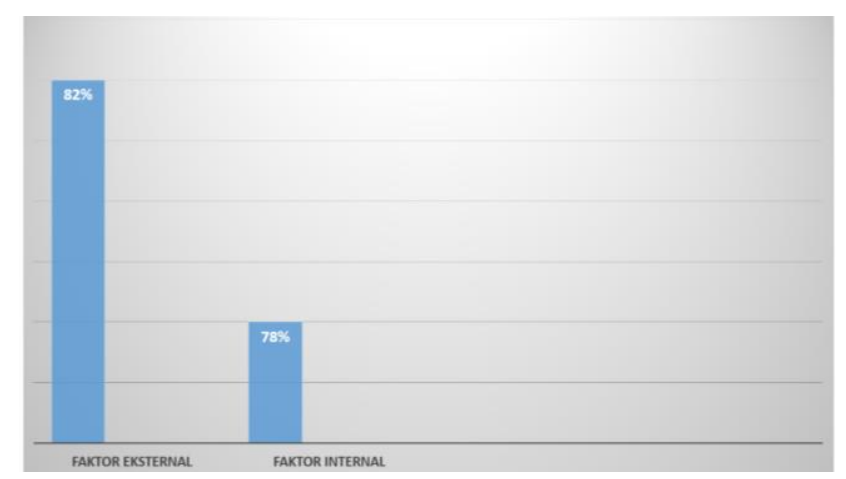

membosankan.

Gambar 10. Faktor Pendukung Pelatihan
Gambar 10 menjelaskan faktor eksternal dan internal yang mendukung pelaksanaan pelatihan menurut evaluasi dari peserta. Ada $82 \%$ peserta pelatihan yang berpendapat bahwa faktor eksternal yang terdiri dari ruang pelatihan, materi pelatihan, pelatih, alat dan media, serta waktu pelaksanaan cukup memadai untuk pelaksanaan pelatihan tersebut. Ada $78 \%$ peserta pelatihan yang berpendapat bahwa faktor internal yaitu motivasi belajar peserta di dalam mengikuti pelatihan cukup tinggi. Persentase faktor eksternal lebih tinggi dari faktor internal. Hal ini menunjukkan bahwa ada $22 \%$ peserta pelatihan yang berpikir bahwa pelatihan ini tidak cukup membantu mereka memecahkan masalah yang mereka hadapi di sekolah. Atau mereka merasa tidak bermasalah dengan pengelolaan kelas, namun bermasalah di bidang lainnya, sehingga mereka beranggapan bahwa pelatihan ini tidak cukup memberikan solusi atas permasalahan yang mereka hadapi.

Jurnal refleksi tiap pertemuan terdiri dari empat bagian yaitu penuangan ide-ide baru, aplikasi yang membantu, hal yang menarik, hal yang belum dipahami dan hal yang ingin diketahui lebih lanjut. Ada beberapa ide baru yang didapat guru selama pelatihan dan dapat diaplikasikan di kelas diantaranya adalah 1) menjadi guru yang efektif melalui penyampaian aturan dan prosedur, kelas yang jelas, pengaturan tempat duduk, dan membangun kesadaran murid untuk bertanggung jawab terhadap pembelajaran mereka; 2) memberikan tugas dan menyusun rubrik penilaian yang jelas; 3) menciptakan ruang kelas yang aman dan nyaman untuk belajar serta menyiapkan pembelajaran dengan maksimal; 4) menyadari panggilan Tuhan sebagai seorang pendidik, bersyukur, dan menginspirasi murid; 5) memiliki semangat untuk melayani murid dengan cara mengenali keunikan karakter mereka; dan 6) memandang murid sebagai ciptaan Tuhan yang memiliki potensi masing-masing.

Hal-hal yang menarik yang ditemukan selama pelatihan adalah sebagai berikut. 1) ice breaking yang berupa gerak dan lagu; 2) berbagi pengalaman mengajar dengan rekan dari departemen lain; 3) menemukan fakta bahwa buku paket bukan satu-satunya sumber mengajar, melainkan guru itu 
sendiri; 4) diskusi kelompok dengan topik yang menarik; 5) aktivitas gallery walk, mind mapping, dan role play per kelompok; dan 6) penjelasan para pelatih yang sopan, jelas, dan tidak terburu-buru serta ceria.

Hal-hal yang belum diketahui dan ingin diketahui oleh para peserta pelatihan adalah sebagai berikut. 1) mengelola kelas SD kecil; 2) menangani ABK supaya tetap merasa dihargai dan diterima kehadirannya; 3) bagaimana menata ruang kelas supaya menarik murid untuk belajar; 4) bagaimana meningkatkan motivasi belajar murid yang rendah; 5) bagaimana membangun kerja sama yang lebih erat dengan sesama guru; 6) bagaimana mengenali karakter murid; 7) mengajar di ruang terbuka; dan 8) merancang pembelajaran yang menyenangkan bagi murid.

\section{KESIMPULAN}

Kesimpulan dari pelaksanaan pelatihan pengelolaan kelas di Sekolah Mardi Yuana Cilegon ini adalah 1) $78 \%$ peserta berpendapat bahwa mereka mendapatkan kesempatan untuk mengingat dan mendiskusikan kembali serta mengaplikasikan di kelas berbagai teori pengelolaan kelas yang efektif; 2) $82 \%$ peserta berpendapat bahwa faktor eksternal seperti ruang dan materi pelatihan, para pelatih, alat dan media serta waktu pelaksanaan yang dipilih cukup mendukung program pelatihan ini; 3) rendahnya motivasi belajar $22 \%$ peserta lainnya perlu ditindaklanjuti oleh para pimpinan sekolah; dan 4) ringkasan jurnal refleksi tiap pertemuan memberikan gambaran bahwa sebagian besar peserta mendapat ide baru dan menarik dari pelatihan yang dapat diaplikasikan di kelas dan mereka memiliki keinginan belajar yang cukup tinggi yang terlihat dari pertanyaan dan pernyataan yang disampaikan secara tertulis.

\section{UCAPAN TERIMAKASIH}

Ucapan terima kasih ditujukan kepada UPH karena telah mendanai kegiatan Pengabdian kepada Masyarakat ini yang berjudul PELATIHAN PENGELOLAAN KELAS (CLASSROOM
MANAGEMENT) BAGI GURU SEKOLAH MARDI YUANA CILEGON UNTUK MENCAPAI TUJUAN PEMBELAJARAN dengan nomor PkM: PM-006-FIP/V/2019.

\section{REFERENSI}

Anditya, N. H., Panggabean, M. S., \& Dirgantoro, K. P. S. (2017). The Role of Christian Teachers in Providing for the Needs of HighAchieving Students. JOHME: Journal of Holistic Mathematics Education, 1(1), 10-21.

Antelm-Lanzat, A. M., Gil, A. J., CacheiroGonzález, M. L., Pérez-Navío, E., \& FonsecaPedrero, E. (2020). Learning Styles and Vocational Guidance in Secondary Education. Educational Sciences: Theory and Practice, 20(3), 1-15.

Brummelen, H. W. V. (2009). Walking with God in the Classroom: Christian Approaches to Teaching and Learning. USA: Purposeful Design.

Johnson, J. F., Uline, C. L., \& Perez, L. G. (2014). The Quest for Mastery. Educational Leadership, 72(2), 48-53.

Miller, J. P., \& Nigh, K. (2017). Holistic Education and Embodied Learning. USA: IAP.

Pitler, H., \& Stone, B. (2012). A Handbook for Classroom Instruction that Works. USA: ASCD.

Standar Pendidik dan Tenaga Kependidikan. (n.d.). BSNP. Retrieved September 19, 2020, from https://bsnp-indonesia.org/standar-pendidikan-dantenaga-kependidikan/

Wong, H. K., \& Wong, R. T. (2009). The First Days of School: How to be an Effective Teacher. CA 94043: Harry K. Wong Publications.

Zendrato, J dkk. (2019). Kurikulum bagi pemula: Tinjauan teori dan aplikasi dalam perspektif kristiani. Jawa Tengah: CV Oase Group.

Zumaeta Arista, S., Fuster Guillen, D., \& Ocaña Fernández, Y. (2018). Pedagogical Affection in Didactics of Mathematics-Amazonas Region from the Phenomenology Perspective. Journal of Educational Psychology - Propositos y Representaciones, 6(1), 437-462. 


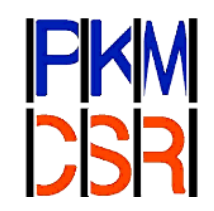

Prosiding PKM-CSR, Vol. 3 (2020)

e-ISSN: 2655-3570 